\title{
The Seven Time Managing Strategies of English Teachers to Adapt with the Change in Curriculum
}

\author{
Lidhya Martaliana, Syahrul Syahrul, and Loli Safitri \\ High School 1 Pasaman, Pasaman, Indonesia \\ lidhyamarta5693@gmail.com
}

\section{ARTICLE HISTORY \\ Received : 5 December 2020 \\ Revised : 31 December 2020 \\ Accepted : 18 February 2021}

\section{KEYWORDS}

Teacher Strategies

Teaching English

Time Management

Change in Curriculum

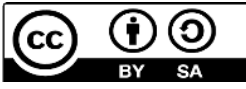

\begin{abstract}
The Indonesian school system curriculum was changed from KTSP to curriculum 2013 (K13) since the year 2013. This alteration of the curriculum dealt an impact by changing the allocated time for English classes. Within KTSP, Teachers taught English subject for four hours session per week, which means four times 45 minutes each week, whereas, within the K13, the allocated time for English subject is a two hours session per week which means two times 45 minutes which means there is a reduction in time for English subject. This study aims to determine how English teachers manage their time by conducting interviews, observations, and documentation analysis on $11^{\text {th }}$ grade English teachers at MAN 1 Pasaman, Indonesia. Findings revealed seven strategies, namely following the school calendar, setting goals and working on achieving those goals, prioritizing the more important goal, making a daily schedule of classroom activities, making a to-do list, setting a time limit for the task in the classroom, and utilising transition time effectively. The findings are a novelty because few studies have identified the specific strategies that English teachers used to successfully adapt to the curriculum change. Thus, this study contributes to future educators preparing and anticipating possible curriculum changes that may drastically change teaching time.
\end{abstract}

\section{Introduction}

Teaching is the concerted sharing of knowledge and experience, which is usually organized with a discipline and, more generally, the provision of stimulus to a person's psychological and intellectual growth by another person or artifact. To achieve the purpose of the teaching, the teacher must have the ability to achieve the desired teaching and learning process in the classroom. So, teaching is the art and science of helping others to grow in their knowledge and understanding. More than that, teaching is a process of teaching moral values, abilities, skills by an experienced person to an inexperienced person to ensure positive change in behavior useful in developing oneself and the society.

Teaching strategy is what teachers use in the classroom to make students achieve the objective of learning. A teacher without a teaching strategy will lead a classroom activity into a monotonous and uninterested class (Wekke, Yandra, \& Hamuddin, 2017). Thus, teaching strategy needs to be seriously considered a factor that can determine the success of students in the classroom. According to Lismay \& Zubaidah (2019), teaching strategy is a special method for solving a problem or task, designing the desired result to manipulate and control the information obtained for the benefit of learning. So, teaching strategy will likely have faced a trial error in the classroom. Still, the good news is there are steps in using a good teaching strategy.
Teaching English is the sharing of English knowledge and experience, which is usually organized to a person's psychological and intellectual growth. There are many reasons why English needs to be taught.

One of the most important abilities that the teacher should have in the teaching and learning process is managing the classroom. Classroom management is a term that the teachers use to ensure the classroom lesson runs smoothly without disruptive behaviour from students compromising the delivery of instruction. According to Sherwood (2008), classroom management refers to teacher behaviours that facilitate learning and a well-managed classroom to increase learning because students spend more time on tasks. It means that classroom management also relates to how teachers use the time effectively, whether on tasks or explanations. However, how teachers manage their classrooms can differ not just based on individuals but also on their experience (Stahnke \& Blömeke, 2021). One of the important aspects of a well-managed classroom is time management. Time management is an essential aspect that the teachers must control. Efficient use of time is an important variable in helping students achieve learning goals and making the classroom a pleasant place for teachers and students. It means the more efficient a teacher manages the time, the better (McLeod, Fisher, \& Hoover, 2003; Van Eerde, 2015). For example, it would be better to spend more time explaining the material or tasks rather than 
punishing students who did not do their homework or spend too much time opening the lesson (Yaldi \& Ariati, 2020).

Time management is planning, organizing, mobilizing, and monitoring productivity time. Time is one of the performance resources that teachers should manage effectively and efficiently. Teachers can see effectiveness from the achievement of the goal using the predetermined time. In classroom learning, the use of time is an important matter (Flower, McKenna, \& Haring, 2017; Wragg, 2001). There is often a limited amount of time available, and its usefulness can be the difference between children. Based on the statement above, students have different abilities in receiving lessons given by the teacher. The teacher should control the time from the beginning until the end of class. According to Adams \& Blair (2019), making effective use of time involves maximizing functions such as starting a task, staying focused, and balancing one task against another. Time management also influences students' achievement results, further driving its importance for English teachers.

Since the year 2013, The government changed the Indonesian school system's curriculum from KTSP to the curriculum of 2013. The curriculum changes may affect the instructional process and decline the teachers' effectiveness in teaching and learning activities. Based on the new curriculum, the teachers need to actively participate in the teaching and learning process as motivators and facilitators so that the students will be the centre of the process.

This alteration of the curriculum also impacts the changes of the teaching and learning activities, including teacher's instruction in the classroom. On the KTSP, Teachers taught English subject for four hours session per week, which means four times 45 minutes each week, whereas, on the curriculum of 2013, the allocated time for English subject is a two hours session per week for compulsory English subject, which means two times 45 minutes.

Curriculum 2013 is a fragment of the previous curriculum. The target of curriculum change is none other than the teacher as the direct implementers in the classroom. While the curriculum is the planned program, teachers are the actors that implement the program through the teaching and learning process. Besides all of that, the teacher also needs to design the lesson plan, teach and evaluating the students.

Designing a lesson plan is not easy. It takes time and energy. Furthermore, the lesson plan is different for each meeting, so the teacher needs to design it for every meeting. Teaching at least requires 90 minutes for each meeting, and a teacher has at least 2 or 3 meetings a day. The last is evaluating the students. Evaluating the students requires much time and energy. For example, checking the students' test needs hours, filling the students' report card cannot be done in just a day, and doing the students' remedial is tiring and time-consuming.
Based on a preliminary interview in MAN 1 Pasaman, the researcher found that English teachers only used one time management strategy in the English teaching-learning process. She used only the to-do-list strategy, while there are many strategies in managing the time that useable to make learning more effective. The teacher also stated that she could reach the learning goals with effective time. Meanwhile, English is a subject that requires much time to comprehend the topics, completing the task. Amazingly, the teacher could do all the teaching process and still can manage their time well. That is one of the reasons why this research is important. So the researcher intends to find out whether it is true the teacher only used one strategy in managing time or using another time management strategy to reach the learning goals with the effective time.

In this study, the researcher focused on teacher's strategies in managing their class times in MAN 1 Pasaman because teachers' time management influences the students' performance. This research is useful because knowing the teacher's strategies in managing time can help the student get more learning time efficiently (Gage et al., 2018). The other motivation behind this research is no research has ever done about the time management strategies that English teachers in particular uses in this specific school.

\section{Method}

This research was carried out at MAN (High School) 1 Pasaman, specifically the English teachers of the Eleventh Grade of 2019/2020 year. The researcher used a qualitative research design to understand the phenomena (Tohirin, 2012), focusing on teachers' actions to manage their time.

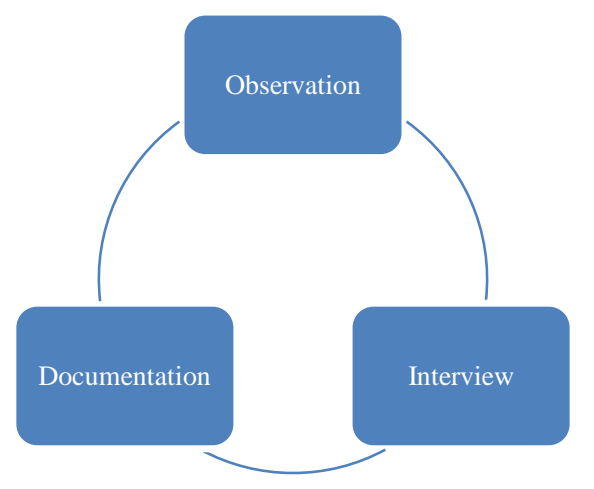

Figure 1. Data Collection Techniques

To collect the data, the researcher used interviews, documentation, and observation, following Burhan's instructions (2012). Data collection by observation was conducted from December 2020 to January 2021 in a participatory manner. To strengthen the observation data, the researcher conducted interviews with the eleventh-grade English teachers of MAN 1 Pasaman. The teachers' 
statements were also supported by statements from the students of XI grade of MAN 1 Pasaman.

This study analysed the data by using the steps set by Sugiyono (2009), which is by reducing the raw data collection to focus on specific aspects or themes, in this case, time management strategies. Finally, the interview and documentation data were also integrated with findings from analysing relevant documents to time management, such as the teachers' to-do lists, regular lesson plans, semester programs, and annual programs.

\section{Results \& Discussion}

The research findings offered an insight into how English teachers adapted to the change of their class durations and demands caused by the change in the curriculum. The researcher found that seven strategies that the teacher used following the school calendar, settings goals and working on achieving those goals, prioritize the more important goals, making a daily schedule of classroom activities, making a to-do list, setting a time limit for the task in the classroom and utilising transition time effectively.

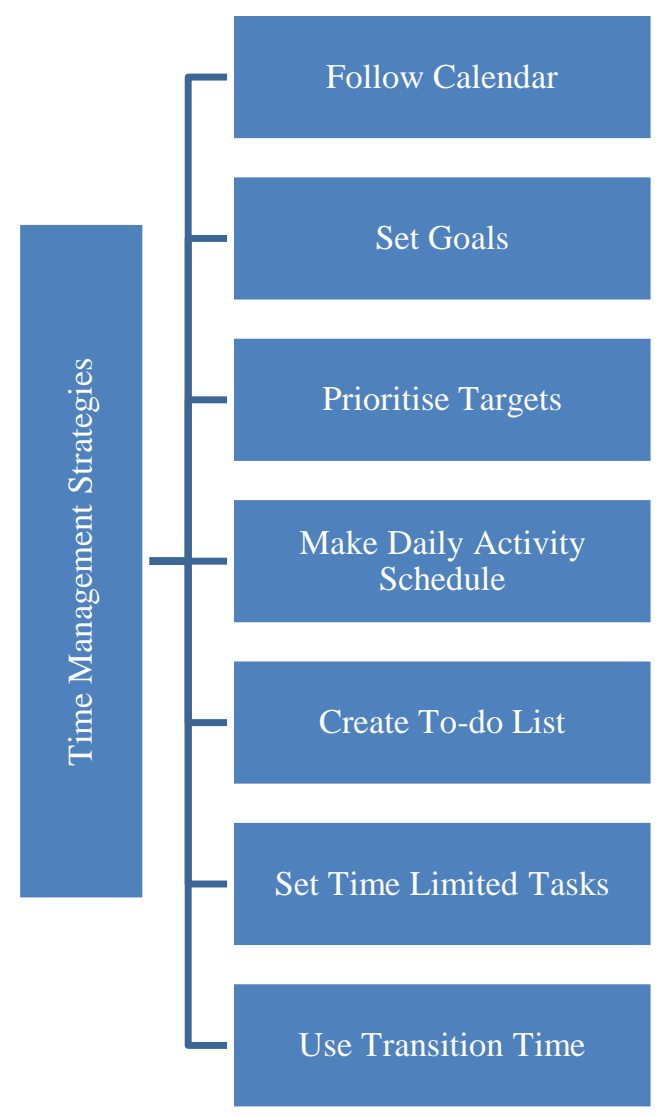

Figure 2. Seven Time Management Strategies
The first strategy is following the school calendar. The School calendar is very influential in managing teaching time in the classroom because it is a teacher's guide. The school calendar is a time setting for learner learning activities during one learning year, which includes, among others, the beginning of the school year, and also holidays. Following the school calendar, the effective week is applied properly, and religious holidays that the school calendar has set can be handled well.

Suppose the school calendar determined religious holidays to coincide with English subjects. In that case, the teacher usually assigns the students assignments to do at home. The assignment could not cover the material that has not been delivered. The teacher would add afternoon classes for the students to replace the time spent by these holidays. The researcher found the following school calendar that strategies used by the teacher - the teacher gave assignments to the students to do at home. The goals were to make students understand the English material better and so that they could apply English learning time well.

The next strategy is setting goals and working on achieving those goals. In this strategy, the teacher sets goals and works to achieve these goals. The teacher must be able to manage the time properly. For example, the teacher puts something more important in teaching based on the lesson plan. The teacher achieved those goals could be seen from the understanding of students in mastering the material and learning outcomes that get a high score. The teacher must have owned goals of success in teaching, especially concerning English subjects. Usually, the teacher will always lack the time to teach because students would not understand the learning material delivered if the teacher only explains it. Usually, the teacher has owned success goals, and the teacher was worked to reach the goals.

The teacher said that the teacher has to manage the time properly, the teacher should achieve those goals. For example, the teacher explains the material, but the teacher also had the best to make students understand the material that has been explained. Students got good grades in English subjects. The teacher explained the subject matter in a way that the students could understand.

The next strategy is to prioritise the more important goals. The interviews revealed that teachers tried to prioritise the students' understanding the subject matter. While it is certainly important and the goal of every lesson, the teachers admitted that certain factors limited them from being able to achieve this goal, such as technical problems or being unable to adjust with a lack of attention when they teach with information technologies. Simangunsong et al. (2019) found identified a similar problem, in which teachers' possible lack of knowledge of ICT can cause them to have difficulties in teaching. Despite technical obstacles, the teachers tried to not leave the class just because of personal whims. The teacher reprimand students who make 
a fuss in the classroom, and the teacher asks students to explain the material that were given by the teacher in front of the class to make students discouraged from making a fuss. The teacher gives additional hours of study to students to cover the lack of time to explain the material that has not been delivered. The teacher gives students homework to do at home and is discussed in subsequent learning to have more understanding about the material that has been explained.

If the students made trouble in the class, they reprimand students who made trouble in the classroom. The teacher's actions were so that other students were not disturbed while the lesson was taking place so, band the teacher pay attention to students about the subject matter delivered by the teacher.

By making a daily schedule in the classroom, the teacher can better manage teaching time. Management of teaching time well, students will have more understanding because they have a target of success in teaching. By making a daily schedule, the teacher plan time effectively. The teacher can think of everything as a whole. Making a daily schedule allows the teacher to plan all activities in the classroom to know what to do without fear of running out of time.

The next strategy is making a to-do list so that the teacher can have a guideline in preparing for their role, and it can manage teaching time can be done well. By making a list, the teacher has been its own guidelines in teaching and management of teaching time could be carried out well, because the teacher would be guided by the list made as the teacher would know about what would be done in the classroom. The teacher would not run out of time when teaching.

The next strategy is setting a time limit for the task in the classroom. Giving students homework can have a good effect on teaching time because students could study independently at home to complete student understanding of the material that has not been conveyed in class because of limitation of time, would be more effective by giving time limits to students in doing homework, because students would have a target time and are more responsible for the tasks that have been given.

From the statement above, the researcher found that teachers think that they would not waste the time by giving time limits to the students in working on a task. The teacher still has time to explained the task that was not understood by these students The teacher interviewed with the students. He said that, when the teacher gives an assignment to students, the teacher set time limits to the students, so the researcher assumes that the teacher's actions so that the time for learning English was not exhausted because the tasks given by the teacher.
The teacher limited the time when doing the assignment to make students understand the responsibilities, so the teacher would not lose the time to explain the next material. If the teacher does not provide the students' time limits, the students would take a long time to do their work, and time would not be enough to explain next material.

The last strategy is to utilize transition time effectively. After changing lessons, the teacher takes 5 minutes to move to the next class, and usually, the teacher directly enters the classroom. Teachers need 15 minutes to open the learning, the time to open learning very influential on student success because if the teacher takes time too long to open the learning and is not in accordance with the time determined by the lesson plan, then the teacher will lack time to deliver the subject matter and adversely affect student success which will make students less understand the material that has been submitted.

The students said that, when the lesson changes over, the teacher directly moved to the next class and did not delay the time to enter the classroom, so teachers could apply the time for opening the lesson plan properly, so the teacher would not be short of time when explaining the subject matter and closing the learning.

\section{Conclusion}

The result researcher found the strategies that the teacher used in teaching English. It can be concluded for the first, the teacher in teaching English in MAN (High School) 1 Pasaman were used seven strategies, The teachers used these strategies to help the teacher in managed the time in teaching at the classroom, make it easier for the teachers to achieve teaching goals in the classroom.

The strategy was used by the teacher: (1) the teacher that guided by the school calendar in managing teaching time, (2) in managing time teachers set goals and working to achieve those goals, (3) the teacher prioritizes the important things first, so that teachers do not run out of time in teaching, and time can be managed properly (4) the teacher makes a daily schedule in the classroom to overcome the lack of teaching time, because the teacher has guidelines in the class set by the school, so the teacher can managed the time as well as possible, (5) the teacher make a list to compile activities that will be carried out by the teacher during teaching in the classroom to help teachers manage time in classroom, (6) the teachers tried to managed the time by setting time limits for students in the work assignments in the classroom, so the teacher will not deficiency teaching time because students follow the rules made by the teacher, and the last (7) the teacher makes the best used of the transition time, the teacher does not linger for long hours, the teacher does not linger in opening the lesson, explains the learning material according to the time specified in lesson plan, and strengthen student understanding by giving assignments. 


\section{References}

Adams, R. V., \& Blair, E. (2019). Impact of time management behaviors on undergraduate engineering students performance. SAGE Open, 9(1), 2158244018824506.

Burhan, B. (2012). Metodologi Penelitian Kualitatif: Aktualisasi Metodologis ke Arah Ragam Varian Kontemporer. PT Rajagrafindo Persada

Flower, A., McKenna, J. W., \& Haring, C. D. (2017). Behavior and classroom management: Are teacher preparation programs really preparing our teachers?. Preventing School Failure: Alternative Education for Children and Youth, 61(2), 163-169.

Gage, N. A., Scott, T., Hirn, R., \& MacSuga-Gage, A. S. (2018). The relationship between teachers' implementation of classroom management practices and student behavior in elementary school. Behavioral Disorders, 43(2), 302-315.

Junaidi, J., Hamuddin, B., Simangunsong, W., Rahman, F., \& Derin, T. (2020). ICT usage in teaching English in Pekanbaru: Exploring junior high school teachers' problems. International Journal of Advanced Science and Technology, 29(3), 5052-5063.

Lismay, L., \& Zubaidah, Z. (2019). Strategi Pembelajaran Bahasa Inggris Mahasiswa Mahad IAIN Bukittinggi. Jurnal Educative: Journal of Educational Studies, 4(1), 45-56.

McLeod, J., Fisher, J., \& Hoover, G. (2003). The key elements of classroom management: Managing time and space, student behavior, and instructional strategies. ASCD.

Morisano, D., Hirsh, J. B., Peterson, J. B., Pihl, R. O., \& Shore, B. M. (2010). Setting, elaborating, and reflecting on personal goals improves academic performance. Journal of applied psychology, 95(2), 255.

Robinson, V. M., Lloyd, C. A., \& Rowe, K. J. (2008). The impact of leadership on student outcomes: An analysis of the differential effects of leadership types. Educational administration quarterly, 44(5), 635-674.

Sherwood, P. (2008). Emotional literacy: The heart of classroom management. Aust Council for $\mathrm{Ed}$ Research.

Stahnke, R., \& Blömeke, S. (2021). Novice and expert teachers' situation-specific skills regarding classroom management: What do they perceive, interpret and suggest?. Teaching and Teacher Education, 98, 103243.
Sugiyono.

(2008). Metode

penelitian pendidikan:(pendekatan kuantitatif, kualitatif dan $R$ $\& D)$. Alfabeta.

Tohirin. (2012). Metode Penelitian Kualitatif dalam Pendidikan. PT Raja Grafindo Persada.

Van Eerde, W. (2015). Time management and procrastination. The psychology of planning in organizations: Research and applications, 12, 312333.

Wekke, I. S., Yandra, A., \& Hamuddin, B. (2017, December). Learning Strategy in Class Management: A Reflection from Manado Case. In IOP Conference Series: Earth and Environmental Science (Vol. 97, No. 1, p. 012053). IOP Publishing.

Wragg, E. C. (2002). Class management in the primary school. Routledge.

Yaldi , D., \& Ariati, J. (2020). The Effect of Reward, Punishment, Interpersonal Communication and Discipline: Economic Course for Social Students Context . Utamax : Journal of Ultimate Research and Trends in Education, 2(2), 44-49. https://doi.org/10.31849/utamax.v2i2.4069 